九州大学学術情報リポジトリ

Kyushu University Institutional Repository

\title{
SIMULTANEOUS DETERMINATION OF KETO AND NON-KETO BILE ACIDS IN HUMAN SERUM BY GAS CHROMATOGRAPHY WITH SELECTED ION MONITORING
}

江口，徹

ht tps://doi. org/10.11501/3056782

出版情報: 九州大学，1991，医学博士，論文博士 バージョン：

権利関係 : 


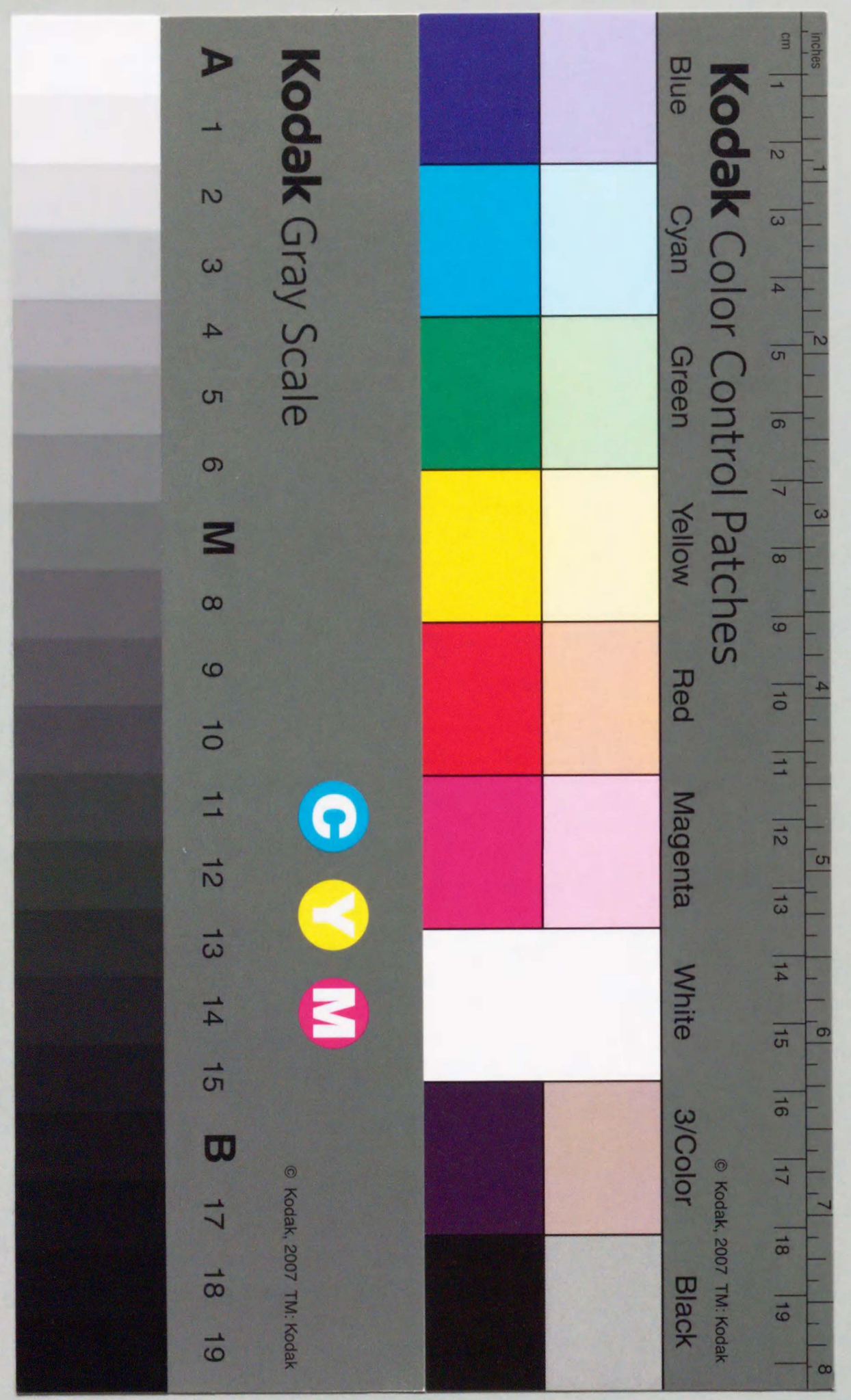

Journal of Chromatography, $525(1990) 25-42$

Biomedical Applications

Elsevier Science Publishers B. V. Amsterdam — Printed in 'The Netherlands

CHROMBIO. 5031

SIMULTANEOUS DETERMINATION OF KETO AND NON-KETO

BILE ACIDS IN HUMAN SERUM BY GAS CHROMATOGRAPHY

WITH SELECTED ION MONITORING

TORU EGUCHI

\section{ELSEVIER}


Journal of ('hromatography, 525 (1990) 25-42

Biomedical Applications

Elsevier Science Publishers B.V.. Amsterdam — Printed in The Netherlands

CHROMBIO. 50:3

SIMULTANEOUS DETERMINATION OF KETO AND NON-KETO

BILE ACIDS IN HUMAN SERUM BY GAS CHROMATOGRAPHY

WITH SELECTED ION MONITORING

TORU EGUICHI

Department of Surgery I, Kyushu ('niversity, Faculty of Medicine, Fukuoka 812 (Japan) HIROSHI MIYAZAKI ${ }^{a}$

Vippon Kayaku ('o. Ltd., Tokyo) 115 (.Japan)

anc

FIMIO NAKAYAMA*

Department of Surgery I, Kivushu ('niversity, Faculty of Medicine, Fukuoka 812 (Japan)

(First received June 19th, 1989: revised manuscript received September 15th, 1989

\section{SUMMARY}

A reliable method for the simultaneous determinat ion of keto and non-ketobile acids in human serum was developed. (arbonyl substituents of bile acid ethyl esters were converted into methyl(oxime and hydroxyl substituents into dimethylethylsilyl ethers and the products were analysed directly by cap illary gas chromatography with selected ion monitoring using $\left|{ }^{2} \mathrm{H}_{4}\right|$ chenodeoxycholic and $\left|{ }^{2} \mathrm{H}_{4}\right| 3 \alpha$-hydroxy-7-oxo-5) $\beta$-cholanoic acids as internal standards. The bile acid peaks on the selected ion chromatogram were separated without interference from endogenous substances present in serum. Recoveries of individual keto bile acids added to serum range from 74.4 to $94.7^{\circ}$ with a mean of $87.1 \%$. Fight kinds of keto bile acids not previously found in sera of normal subjects.

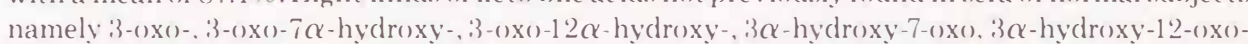

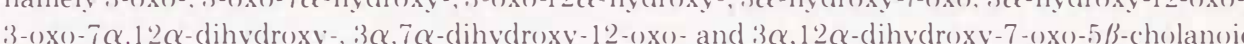
acids were identified and quantified. The total concentration of keto bile acids was found to be

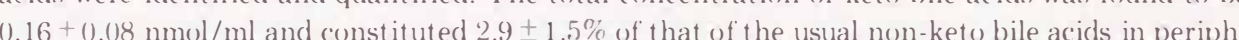
ral venous serum.

"Present address: Second Department of Internal Medicine, Showa Iniversity Sichool of Medi(ine. Shinagawa-ku. 'Tokyo 142. Japan.

(0)378-4:347/90/(0/303.50

(c) 1990) Elsevier Science Publishers B.V. 
INTRODTC:TION

Recently, interest has been focused on the relative amounts of the metabolites produced during bile acid transformations in relation to their role in health and disease states. Keto bile acids, believed to be produced mainly by bacteria dehydrogenation in the intestine $[1,2]$, are one of the major constituents in human faeces [3-6], whereas human bile normally contains only traces of these compounds [7]. The presence of 7- or 12-oxo bile acids has been noted in bile [8-12], urine [13-15], serum [16,17] and liver tissue [18] in hepatobiliary and intestinal disorders.

Various methods have been applied to the determination of keto bile acids in biological materials with some difficulties. In gas chromatography (GC) on conventional-packed columns, bile acids with unprotected carbonyl groups produce broad peaks with long retention times and are not suitable for quantification. The potential formation of enol esters during silylation [19] may add to the difficulties.

The microdetermination of keto bile acids would require high sensitivity and specificity, as these acids are only minor components of the complex profile of bile acids. In this work, in order to improve the reliability of determination, keto bile acids were determined as the ethyl ester (Et) methyloxime dimethylethylsilyl (MO-DMES) ether derivatives on a fused-silica capillary column chemically bonded with a non-selective liquid phase using GC with selected ion monitoring (GC-SIM). This method could be applied to the simultaneous determination of keto and non-keto bile acids in serum. The profiles of serum keto and non-keto bile acids of normal subjects thus measured are reported for the first time.

EXPERIMENTAL,

Subjects

The subjects were ten healthy males aged between 27 and 41 years with no clinical evidence of liver disease. Serum bilirubin, albumin, glutamic oxaloacetic transaminase, glutamic pyruvic transaminase and alkaline phosphatase were all within normal ranges. Serum was obtained after overnight fasting and stored at $-20^{\circ} \mathrm{C}$ until analysis.

\section{Chemicals}

All solvents were of analytical-reagent grade and were distilled before use. Pyridine was dried by refluxing with potassium hydroxide prior to distillation and stored over potassium hydroxide. Dimethylethylsilylimidazole (DMESI) and $\mathrm{O}$-methylhydroxylamine hydrochloride $(\mathrm{MOA} \cdot \mathrm{HCl})$ were obtained from Tokyo Kasei Kogyo (Tokyo, Japan). TMSI-H [hexamethyldisilazane-trimethylchlorosilane-pyridine $(2: 1: 10, \mathrm{v} / \mathrm{v})]$ was purchased from Gasukuro
Kogyo (Tokyo, Japan). Ethanolic and methanolic hydrogen chloride (5\%, $\mathrm{w} / \mathrm{v}$ ) were prepared by introducing dry hydrogen chloride gas into ethanol and methanol, respectively.

$\left[11,11,12,12-{ }^{2} \mathrm{H}_{4}\right] 3 \alpha$-Hydroxy-7-oxo-5 $\beta$-cholanoic acid $\left(\left[{ }^{2} \mathrm{H}_{4}\right] 7 \mathrm{KLCA}\right)$ was prepared by treating $\left[11,11,12,12-{ }^{2} \mathrm{H}_{4}\right]$ chenodeoxycholic acid with $7 \alpha$ hydroxysteroid dehydrogenase ( $7 \alpha$-HSD, EC 1.1.1.159) (Sigma, St. Louis, MO U.S.A.). The resulting 7KLCA was purified by preparative thin-layer chromatography (TLC) using benzene-dioxane-acetic acid $(70: 20: 2, \mathrm{v} / \mathrm{v})$ as the solvent. The purity was checked by TLC and GC (>98\%).3-Oxo-7 $\beta$-hydroxy$5 \beta$-cholanoic acid $(3 \mathrm{~K} 7 \beta)$ was prepared in our laboratory with $3 \alpha$-hydroxysteroid dehydrogenase ( $3 \alpha$-HSD, EC 1.1.1.50) (Sigma) from ursodeoxycholic acid. 3-Oxo- $7 \alpha$-hydroxy-5 $\beta$-cholanoic acid $(3 \mathrm{~K} 7 \alpha)$ and 3-oxo- $12 \alpha$-hydroxy$5 \beta$-cholanoic acid ( $3 \mathrm{~K} 12 \alpha)$ were kindly supplied by Nippon Kayaku (Tokyo, Japan ); 3 -oxo- $7 \alpha, 12 \alpha$-dihydroxy-5 $\beta$-cholanoic acid $(3 \mathrm{~K} 7 \alpha 12 \alpha)$ was obtained from Research Plus (Philadelphia, PA, U.S.A.). Other authentic keto bile acids were purchased from Steraloids (Wilton, NH, U.S.A.). Other reagents and authentic and deuterated bile acids used were the same as in previous studies $[18,20]$.

Thin-layer chromatography

TLC was carried out using precoated Kieselgel 60 plates (Merck, Darmstadt, F.R.G.) with benzene-dioxane-acetic acid $(70: 20: 2, \mathrm{v} / \mathrm{v})$ as solvent.

Gas chromatography

A Shimadzu GC-15A PFsc gas chromatograph equipped with a flame ionization detector, a Van den Berg solventless injector and a Chromatopac C-R3A data-processing system (Shimadzu, Kyoto, Japan) was employed. It was fitted with a fused-silica capillary column chemically bonded with HiCap-CBP1 (Shimadzu) non-polar methylsilicone stationary phase (equivalent to OV-1) ( $20 \mathrm{~m} \times 0.2 \mathrm{~mm}$ I.D. ). The temperature of the column oven was maintained at $275^{\circ} \mathrm{C}$. The carrier gas (helium) linear velocity was $40 \mathrm{~cm} / \mathrm{s}$. The methylene unit (MU) value was determined using $\mathrm{C}_{28}-\mathrm{C}_{38} n$-alkanes.

Gas chromatography-mass spectrometry

Gas chromatographic-mass spectrometric (GC-MS) analysis was performed using a Shimadzu Auto GC-MS 9020DF instrument equipped with a Shimadzu SCAP 1123 data-processing system. The injection device, column and operating conditions were the same as in GC. The ionization energy and trap current were $20 \mathrm{eV}$ and $60 \mu \mathrm{A}$, respectively. The mass spectrometer was scanned from $\mathrm{m} / z 100$ to 700 under computer control at 4.5-s intervals to obtain the mass spectra. Selected ion monitoring (SIM) was carried out using a multiple ion detector. 
Derivatization

To samples containing keto and non-keto bile acids, $0.5 \mathrm{ml}$ of $5 \%(\mathrm{w} / \mathrm{v})$ ethanolic hydrogen chloride was added and the mixture was allowed to stand for $60 \mathrm{~min}$ at room temperature [21]. The solution was evaporated to dryness under reduced pressure. The ethyl esters were dissolved in $0.1 \mathrm{ml}$ of pyridine containing $10 \mathrm{mg}$ of $\mathrm{MOA} \cdot \mathrm{HCl}$. After reaction in a small Teflon-stoppered test-tube, the reaction mixture was cooled to room temperature, then $50 \mu \mathrm{l}$ of DMESI were added, the mixture was allowed to stand for $30 \mathrm{~min}$ at room temperature [21] and excess of reagent was removed using a Sephadex LH-20 column with chloroform- $n$-hexane-methanol $(20: 20: 1, \mathrm{v} / \mathrm{v})$ as eluent $[20,22]$ The eluate was evaporated to dryness and the residue was dissolved in $1 \%$ pyridine- $n$-hexane and subjected to GC and GC-MS

The preparation of the Et-DMES ethers of keto bile acids was performed as described above except for the conversion of methyloxime. To prepare the methyl ester trimethylsilyl (Me-TMS) ethers of bile acids, $0.5 \mathrm{ml}$ of $5 \%$ $(\mathrm{w} / \mathrm{v})$ methanolic hydrogen chloride was added and the mixture was allowed to stand for $60 \mathrm{~min}$ at room temperature [23]. After evaporation to dryness the residue was treated with $50 \mu \mathrm{l}$ of TMSI-H [24].

Clean-up procedure

Serum samples were treated as described previously [18,20,25] with some minor modifications. After the addition of suitable amounts of internal stan dards to $0.2-0.5 \mathrm{ml}$ of serum, the mixture was diluted with four volumes of 0 . $M$ sodium hydroxide solution. The mixture was incubated at $65^{\circ} \mathrm{C}$ for $15 \mathrm{~min}$ and passed through a Bond-Elut $\mathrm{C}_{18}$ cartridge (Analytichem International, Harbor City, CA, U.S.A.) followed by washing with $5 \mathrm{ml}$ of water. Bile acids were eluted with $5 \mathrm{ml}$ of $90 \%$ ethanol. The eluate was evaporated to drynes under reduced pressure and the residue was dissolved in $2 \mathrm{ml}$ of $0.1 \mathrm{M}$ acetate buffer ( $\mathrm{pH} 5.6$ ). For hydrolysis, $0.2 \mathrm{ml}$ of $0.2 \mathrm{M} \beta$-mercaptoethanol, $0.2 \mathrm{ml}$ of $0.2 M \mathrm{Na}_{2}$ EDTA and $1 \mathrm{U}$ of partially purified cholylglycine hydrolase (EC 3.5.1.24) (Sigma) were added and incubated at $37^{\circ} \mathrm{C}$ for $18 \mathrm{~h}$. The deconjugated bile acids were extracted with a Bond-Elut $\mathrm{C}_{18}$ cartridge. After removal of ethanol under reduced pressure, solvolysis was performed in $1 \mathrm{ml}$ of ethanol plus $9 \mathrm{ml}$ of equilibrated ethyl acetate (with $2 \mathrm{M}$ sulphuric acid) at $37^{\circ} \mathrm{C}$ for $18 \mathrm{~h}[13,26]$. The mixture was neutralized with sodium hydroxide solution and evaporated to dryness. The residue was dissolved in $4 \mathrm{ml}$ of distilled water and acidified to $\mathrm{pH} 1$ with $2 M$ hydrochloric acid. The free bile acids were extracted three times with $4 \mathrm{ml}$ of ethyl acetate and derivatized.

Identification and determination of individual bile acids

The individual bile acid derivatives were identified by comparing the MU values of peaks on the selectedion chromatograms and mass spectra with those of the corresponding authentic bile acids.
Quantification was carried out by GC-SIM. Although 3-oxo groups formed syn and anti isomers, one peak of the isomers that was not disturbed by the other peaks was used for quantification. Quantification of 7KLCA, which overlapped the second isomer peak of $3 \mathrm{~K} 7 \alpha$, was done by subtracting the area of the second isomer peak, calculated by multiplying the area of the clearly separated first isomer peak by the ratio of the areas of the syn and anti isomers.

\section{RESULTS}

Derivatization

For esterification, bile acids were treated with dry ethanolic hydrogen chloride $(5 \%, \mathrm{w} / \mathrm{v})$ in order to avoid the possible occurrence of side-reactions [23] Their ethyl esters gave a single spot on TLC. The reaction rates of carbonyl groups of 3 -oxo- $5 \beta$-cholanoic acid (3K), 7KLCA and $3 \alpha$-hydroxy-12-oxo- $5 \beta$ cholanoic acid (12KLCA) ethyl esters during conversion to the methyloximes at 60 or $110^{\circ} \mathrm{C}$ with $10 \%(\mathrm{w} / \mathrm{v}) \mathrm{MOA} \cdot \mathrm{HCl}$ in pyridine were tested. Fig. 1 shows the time course of the formation of the methyloximes. Methyloxime formation follows from 3-oxo, 12-oxo and 7-oxo groups in this order. Methyloxime for-

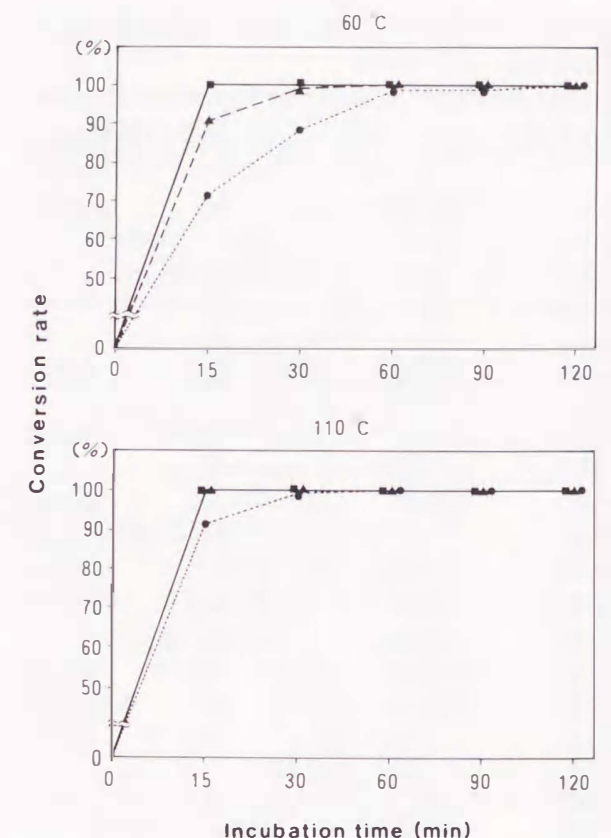

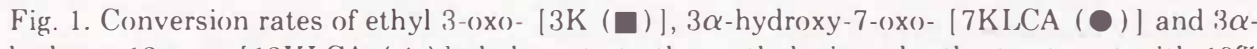
hydroxy-12-0xo- $[12 \mathrm{KLCA}(\boldsymbol{\Delta})]$ cholanoate to the methyloximes by the treatment with $10 \%$ methoxyamine hydrochloride in pyridine at $60^{\circ} \mathrm{C}$ (above) and at $110^{\circ} \mathrm{C}$ (below). The samples were silylated with DMESI prior to $\mathrm{GC}$ analysis. 
mation was completed over $90 \mathrm{~min}$ at $60^{\circ} \mathrm{C}$ and within $60 \mathrm{~min}$ at $110^{\circ} \mathrm{C}$. Under these conditions, no by-product was observed by GC and TLC. Hydroxyl groups in the Et-MO derivatives of keto bile acids were found to be readily silylated with DMESI and TMS-imidazole [19].

Gas chromatographic behaviour of keto bile acids

Table I gives the methylene unit values for the Me-TMS ethers, Et-DMES ethers and Et-MO-DMES ethers of keto and non-keto bile acids on a HiCapCBP1 capillary column. Depending on the positions of the keto groups present, the $s y n$ and anti isomers of MO derivatives were eluted either together or separately as in the GC analysis of keto steroids [27]. Two isomers of 3-methoxyloxime derivatives, i.e. $3 \mathrm{~K} 7 \alpha, 3 \mathrm{~K} 7 \beta, 3 \mathrm{~K} 7 \alpha 12 \alpha, 3,7$-dioxo- $5 \beta$-cholanoic acid

T'ABLEI I

METHYLENE UNIT VAL,UES OF THREE KINDS OF DERIVATIVES OF BILE ACIIS AND) (HOLLESTEROI

Methylene unit values were determined at $275^{\circ} \mathrm{C}$. Me-TMS = methyl ester trimethylsilyl ether Et-T.MFS =ethyl ester dimethylethylsilyl ester; Et-MO-DMES=ethyl ester methyloxime dimethylethylsilyl ether.

\begin{tabular}{|c|c|c|c|c|}
\hline \multirow[t]{2}{*}{ ('ompound ${ }^{a}$} & \multirow[t]{2}{*}{ Abbreviation } & \multicolumn{3}{|c|}{ Methylene unit value } \\
\hline & & Me-TMS & Et-DMFS & Et-MO-DMES \\
\hline 5) $/ 3 \mathrm{~B}-3$-one & $3 \mathrm{~K}$ & 31.82 & 32.40 & 32.80 \\
\hline $5 / \beta \mathrm{B}-7 \alpha-0)-3-0$ ne & $3 \mathrm{~K} 7 \alpha$ & 32.91 & 34.58 & $34.333,34.62$ \\
\hline $5 / \beta \mathrm{B}-7 / \beta-0 \mathrm{ol}-3$-one & $3 \mathrm{~K} 7 \beta$ & 33.24 & 35.00 & $35.11,35.33$ \\
\hline $5 / \beta \mathrm{B}-12 \alpha-01-3-$-one & $3 \mathrm{~K} 12 \alpha$ & 32.54 & 34.07 & $34.20^{b}$ \\
\hline $5 / \beta \mathrm{B}-3 \alpha-01-7-0 \mathrm{ne}$ & $7 \mathrm{KLCA}$ & 33.29 & 35.12 & 34.60 \\
\hline $5 \beta \mathrm{B}-3 \alpha$-ol-12-one & $12 \mathrm{KLCA}$ & 33.28 & 35.09 & 33.88 \\
\hline 5) $\beta \mathrm{B}-7 \alpha, 12 \alpha$-diol-3-one & $3 \mathrm{~K} 7 \alpha 12 \alpha$ & 33.41 & 36.18 & $35.54,35.87$ \\
\hline 5) $\beta \mathrm{B}-3 \alpha, 12 \alpha$-diol-7-one & $7 \mathrm{KDCA}$ & 33.95 & 36.62 & 35.50 \\
\hline 5) $\beta \mathrm{B}-3 \alpha, 7 \alpha$-diol-12-one & $12 \mathrm{KCDCA}$ & 34.16 & 36.94 & 35.17 \\
\hline 5) $\beta \mathrm{B}-3,7$-dione & $3,7 \mathrm{DK}$ & 33.27 & 33.92 & $34.17,34.42$ \\
\hline 5/3B-3,12-dione & $3,12 \mathrm{DK}$ & 33.28 & 33.99 & $33.62^{b}$ \\
\hline $5 / \beta \mathrm{B}-3 \alpha-0 \mathrm{l}-7,12$-dione & $3 \alpha 7,12 \mathrm{DK}$ & 34.72 & 36.61 & 35.01 \\
\hline $5 / \beta \mathrm{B}-3,7,12$-trione & DHCA & 34.44 & 35.12 & $34.86,35.05$ \\
\hline$\left(c^{5}-3 / 3-0\right)$ & $\mathrm{CH}$ & 31.57 & 32.86 & \\
\hline $5 / \beta \mathrm{B}-3 \alpha-0)$ & LCA & 31.43 & 33.27 & \\
\hline $\mathrm{B}^{5}-3 \beta-01$ & $3 \beta \mathrm{B}^{5}$ & 32.20 & 34.20 & \\
\hline $5 / \beta \mathrm{B}-3 \alpha, 12 \alpha$-diol & DCA & 32.02 & 34.71 & \\
\hline $5 / \beta \mathrm{B}-3 \alpha, 7 \alpha$-diol & CDCA & 32.24 & 35.02 & \\
\hline $5 / \beta \mathrm{B}-3 \alpha, 7 \beta$-diol & UIDCA & 32.58 & 35.39 & \\
\hline $5 / 3 \mathrm{~B}-3 \alpha, 7 \alpha, 12 \alpha$-triol & $\mathrm{CA}$ & 32.34 & 36.23 & \\
\hline
\end{tabular}

$\mathrm{B}=$ cholanoic acid, $\mathrm{C}=$ cholestane; the superscript indicates the position of the double bond ${ }^{b}$ These peaks were broad and asymmetric.
$(3,7 \mathrm{DK})$ and 3,7,12-trioxo-5 $\beta$-cholanoic acid (DHCA) were separated, whereas $3 \mathrm{~K}, 3 \mathrm{~K} 12 \alpha$ and 3,12 -dioxo-5 $\beta$-cholanoic acid $(3,12 \mathrm{DK})$ gave a single peak. However, $3 \mathrm{~K} 12 \alpha$ and 3,12DK gave broad and asymmetric peaks. All MO derivatives of the 7- and 12-oxo bile acids were observed as a single peak.

The Et-MO-DMES ether derivatives of monooxo bile acids were eluted according to the number of hydroxyl groups present, but not the number of carbonyl groups, i.e. no general order of elution was observed. The Et-MO-DMES ether derivatives of almost all keto bile acids were eluted earlier than the corresponding Et-DMES derivatives. Although the Et-DMES ether derivatives of 7KLCA and 12KLCA and the ethyl ester of DHCA gave similar MU values, their corresponding MO derivatives were completely separated. Moreover, the Et-MO derivatives of $3,7 \mathrm{DK}$ and $3,12 \mathrm{DK}$, which gave similar MU values with free oxo groups, showed complete separation. However a baseline separation of all derivatives of bile acids with hydroxyl and/or keto groups could not be obtained.

Gas chromatography-mass spectrometry of Et-MO-DMES ether derivatives

The mass spectra of the Et-MO-DMES ether derivatives are summarized in Table II. The ions due to elimination of $\mathrm{C}_{2} \mathrm{H}_{5}(\mathrm{M}-29), \mathrm{OCH}_{3}(\mathrm{M}-31)$,

TABLE II

MASS SPECTRA OF Et-MO-DMES ETHER DERIVATIVES OF KETO BILE ACIDS

Abbreviations as in Table I. Values in parentheses represent the relative intensities (\%)

\begin{tabular}{|c|c|c|c|c|c|c|c|c|}
\hline \multirow[t]{2}{*}{ Bile acid } & \multirow[t]{2}{*}{$M_{r}^{a}$} & \multicolumn{7}{|c|}{ Characteristic ions $(\mathrm{m} / \mathrm{z})$} \\
\hline & & {$\left[\mathrm{M}^{+}\right]$} & {$\left[\mathrm{M}-\mathrm{C}_{2} \mathrm{H}_{5}\right]^{+}$} & {$\left[\mathrm{M}-\mathrm{OCH}_{3}\right]^{+}$} & Other ions & & & \\
\hline $3 \mathrm{~K}$ & 431 & $431(36)$ & $402(6)$ & $400(100)$ & $383(13)$ & $344(15)$ & $3: 30(20)$ & $302(15)$ \\
\hline \multirow[t]{2}{*}{$3 \mathrm{~K} 7 \alpha^{b}$} & 533 & $533(4)$ & $504(2)$ & $502(-)$ & $429(5)$ & $398(100)$ & $382(7)$ & $328(8)$ \\
\hline & & $533(4)$ & $504(-)$ & $502(-)$ & $429(5)$ & $398(100)$ & $382(7)$ & $328(9)$ \\
\hline \multirow[t]{2}{*}{$3 \mathrm{~K} 7 \beta^{6}$} & 533 & $533(-)$ & $504(42)$ & $502(67)$ & $474(27)$ & $472(26)$ & $398(100)$ & $352(88)$ \\
\hline & & $533(-)$ & $504(43)$ & $502(100)$ & $474(6)$ & $472(7)$ & $398(38)$ & $352(20)$ \\
\hline $3 \mathrm{~K} 12 \alpha$ & 533 & $533(5)$ & $504(15)$ & $502(5)$ & $472(20)$ & $398(100)$ & $352(28)$ & $300(19)$ \\
\hline $7 \mathrm{KLCA}$ & 533 & $533(15)$ & $504(-)$ & $502(14)$ & $429(39)$ & $398(100)$ & $383(8)$ & $300(15)$ \\
\hline $12 \mathrm{KLCA}$ & 533 & $533(9)$ & $504(10)$ & $502(67)$ & $446(11)$ & $398(7)$ & $383(6)$ & $364(100)$ \\
\hline \multirow[t]{2}{*}{$3 \mathrm{~K} 7 \alpha 12 \alpha^{6}$} & 635 & $635(-)$ & $606(-)$ & $604(-)$ & $427(10)$ & $396(100)$ & $298(6: 3)$ & \\
\hline & & $635(-)$ & $606(-)$ & $604(-)$ & $427(10)$ & $396(100)$ & $298(68)$ & \\
\hline $7 \mathrm{KDC}$ & 635 & $635(6)$ & $606(100)$ & $604(20)$ & $531(25)$ & $500(32)$ & $396(24)$ & \\
\hline $12 \mathrm{KCDCA}$ & 635 & $635(11)$ & $606(14)$ & $604(61)$ & $500(14)$ & $466(100)$ & $396(32)$ & \\
\hline \multirow[t]{2}{*}{$3,7 \mathrm{DK}^{b}$} & 474 & $474(57)$ & $445(13)$ & $443(73)$ & $444(46)$ & $411(100)$ & $402(21)$ & $375(18)$ \\
\hline & & $474(31)$ & $445(29)$ & $443(46)$ & $444(100)$ & $411(48)$ & $402(9)$ & $375(27)$ \\
\hline $3,12 \mathrm{DF}$ & 474 & $474(10)$ & $445(4)$ & $443(74)$ & $429(13)$ & $387(14)$ & $305(100)$ & \\
\hline $3 \alpha 7,12 \mathrm{DK}$ & 576 & $576(2)$ & 54 & $545(100)$ & $531(9)$ & $513(16)$ & $441(6)$ & $409(9)$ \\
\hline \multirow[t]{2}{*}{$\mathrm{DHCA}^{b}$} & 517 & $517(3)$ & $488(7)$ & $486(100)$ & $472(7)$ & $454(16)$ & $348(10)$ & \\
\hline & & $517(2)$ & $488(6)$ & $486(100)$ & $472(5)$ & $454(9)$ & $348(6)$ & \\
\hline
\end{tabular}

aRelative molecular masses of the derivatives.

tThese keto bile acids gave syn and ant $i$ isomers. 
DMESOH $(M-104)$ and side-chain $(M-129)$ from the molecular ion were observed in the mass spectra of the Et-MO-DMES ether derivatives of compounds with 3- and 7-oxo groups. In the mass spectra of the 12-methyloxime derivatives, the ions due to the fission of the $\mathrm{D}$-ring $(\mathrm{M}-169)$ were observed as dominant peaks [28]. The fragmentations of syn and anti isomers of the MO derivatives of 3-oxo bile acids were very similar, whereas the relative intensities of fragment ions between syn and anti isomers were different. $\mathrm{Al}$ though the Et-DMES ether derivatives of 3K, 12KLCA, 12KCDCA, 3,12DK, $3 \alpha$-hydroxy-7,12-dioxo- $5 \beta$-cholanoic acid $(3 \alpha 7,12 \mathrm{DK})$ and DHCA with free oxo groups did not show intense ions in the high-mass region, their Et-MODMES ether derivatives gave intense ions at $[\mathrm{M}-31]^{+}$or $[\mathrm{M}-169]^{+}$above $\mathrm{m} / \mathrm{z} 300$. Prominent ions given by the individual keto bile acid derivatives were used for monitoring by GC-SIM (Table III) and the peak areas in the selected ion chromatogram were calculated for the quantification. A constant ratio of syn and anti isomers was obtained by the use of a definite concentration of

TABLE III

MONITORING IONS OF INDIVIDUAL BILE ACIDS AND CHOLFSTEROL FOR (IC-SIM The bile acid ethyl esters were converted to the MO-DMES ether or DMES ether derivatives and cholesterol was converted to I)MES ether prior to the analysis.

\begin{tabular}{llll}
\hline $\begin{array}{l}\text { Compound } \\
\text { designation }\end{array}$ & Component & $\begin{array}{l}\text { Monitoring } \\
\text { ion }(\mathrm{m} / \mathrm{z})\end{array}$ & Fragment \\
\hline $\mathrm{a}$ & $3 \mathrm{~K}$ & 400 & {$\left[\mathrm{M}-\mathrm{OCH}_{3}\right]^{+}$} \\
$\mathrm{b}$ & $3 \mathrm{~K} 7 \alpha$ & 398 & {$\left[\mathrm{M}-\mathrm{OCH}_{3}-\mathrm{DMESOH}\right]^{+}$} \\
$\mathrm{c}$ & $3 \mathrm{~K} 12 \alpha$ & 398 & {$\left[\mathrm{M}-\mathrm{OCH}_{3}-\mathrm{DMESOH}\right]^{+}$} \\
$\mathrm{d}$ & $7 \mathrm{KLCA}$ & 398 & {$\left[\mathrm{M}-\mathrm{OCH}_{3}-\mathrm{DMESOH}\right]^{+}$} \\
$\mathrm{e}$ & $12 \mathrm{KLCA}$ & 364 & {$[\mathrm{M}-169]^{+}$} \\
$\mathrm{f}$ & $3 \mathrm{~K} 7 \alpha 12 \alpha$ & 396 & {$\left[\mathrm{M}-\mathrm{OCH}_{3}-2 \times \mathrm{DMESOH}\right]^{+}$} \\
$\mathrm{g}$ & $7 \mathrm{KDCA}$ & 606 & {$\left[\mathrm{M}-\mathrm{C}_{2} \mathrm{H}_{5}\right]^{+}$} \\
$\mathrm{h}$ & $12 \mathrm{KCDCA}$ & 466 & {$[\mathrm{M}-169]^{+}$} \\
$\mathrm{i}$ & $3,7 \mathrm{DK}$ & 411 & {$\left[\mathrm{M}-2 \mathrm{OCH}_{3}-\mathrm{H}\right]^{+}$} \\
$\mathrm{j}$ & $3,12 \mathrm{DK}$ & 443 & {$\left[\mathrm{M}-\mathrm{OCH}_{3}\right]^{+}$} \\
$\mathrm{k}$ & $3 \alpha 7,12 \mathrm{DK}$ & 545 & {$\left[\mathrm{M}-\mathrm{OCH}_{3}\right]^{+}$} \\
l & $\mathrm{DHCA}$ & 486 & {$\left[\mathrm{M}-\mathrm{OCH}_{3}\right]^{+}$} \\
$\mathrm{m}$ & $\left.{ }^{2} \mathrm{H}_{4}\right] 7 \mathrm{KLCA}$ & 402 & {$\left[\mathrm{M}-\mathrm{OCH}_{3}-\mathrm{DMESOH}\right]^{+}$} \\
$\mathrm{n}$ & $\mathrm{CH}$ & 443 & {$\left[\mathrm{M}-\mathrm{C}_{2} \mathrm{H}_{5}\right]^{+}$} \\
& $\mathrm{LCA}$ & 461 & {$\left[\mathrm{M}-\mathrm{C}_{2} \mathrm{H}_{5}\right]^{+}$} \\
& $3 \beta \mathrm{B}^{5}$ & 459 & {$\left[\mathrm{M}-\mathrm{C}_{2} \mathrm{H}_{5}\right]^{+}$} \\
& ICA & 563 & {$\left[\mathrm{M}-\mathrm{C}_{2} \mathrm{H}_{5}\right]^{+}$} \\
& $\mathrm{CDCA}$ & 459 & {$\left[\mathrm{M}-\mathrm{C}_{2} \mathrm{H}_{5}-\mathrm{DMFSOH}\right]^{+}$} \\
& $\mathrm{UDCA}$ & 563 & {$\left[\mathrm{M}-\mathrm{C}_{2} \mathrm{H}_{5}\right]^{+}$} \\
& $\mathrm{CA}$ & 665 & {$\left[\mathrm{M}-\mathrm{C}_{2} \mathrm{H}_{5}\right]^{+}$} \\
& $\left.{ }^{2} \mathrm{H}_{4}\right] \mathrm{CDCA}$ & 463 & {$\left[\mathrm{M}-\mathrm{C}_{2} \mathrm{H}_{5}-\mathrm{DMESOH}\right]^{+}$} \\
\hline & &
\end{tabular}

${ }^{a}$ Corresponding designations are used in the figures.
TABLE IV

RELATIVE AREA OF SYN AND ANTI ISOMERS OF THE Et-MO-DMES ETHER DERIVATIVES OF 3-OXO BILE ACIDS

The peak area of the second-eluted isomer was divided by that of the first-eluted isomer in the selected ion chromatogram.

\begin{tabular}{|c|c|c|}
\hline 3-Oxo bile acid ${ }^{a}$ & $n$ & $\begin{array}{l}\text { Relative area } \\
\text { (mean } \pm \text { S.I).) }\end{array}$ \\
\hline $3 \mathrm{~K} i \alpha$ & 10 & $0.96 \pm 0.07$ \\
\hline $3 \mathrm{~K} 7 \alpha 12 \alpha$ & 12 & $0.76 \pm 0.03$ \\
\hline $3.7 \mathrm{JK}$ & 12 & $0.38 \pm 0.01$ \\
\hline I) HCA & 12 & $0.90 \pm 0.03$ \\
\hline
\end{tabular}

a:3-0xo-, 3-0xo-12 $\alpha$-hydroxy- and 3,12-dioxocholanoic acid gave single peaks.

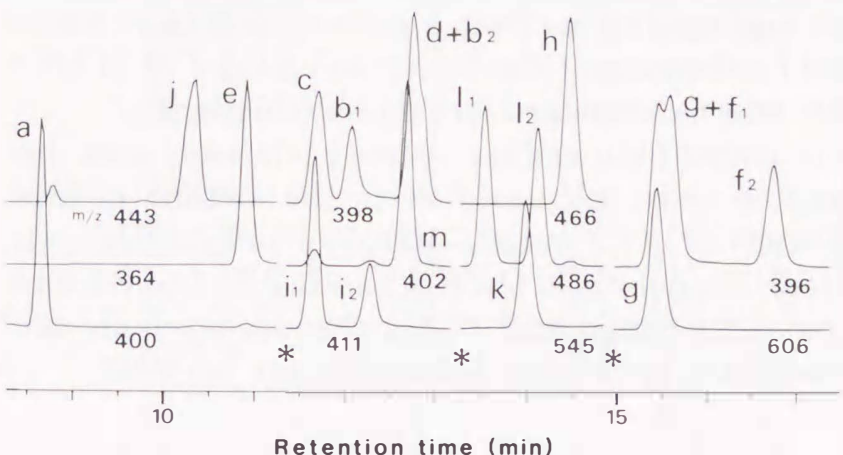

Fig. 2. Selected ion chromatogram of the Et-MO-DMES ether derivatives of the authentic mixture of keto bile acids ( $\mathrm{a}-\mathrm{m}$, Table III). Monitoring ions were changed at the positions indicated by the asterisks.

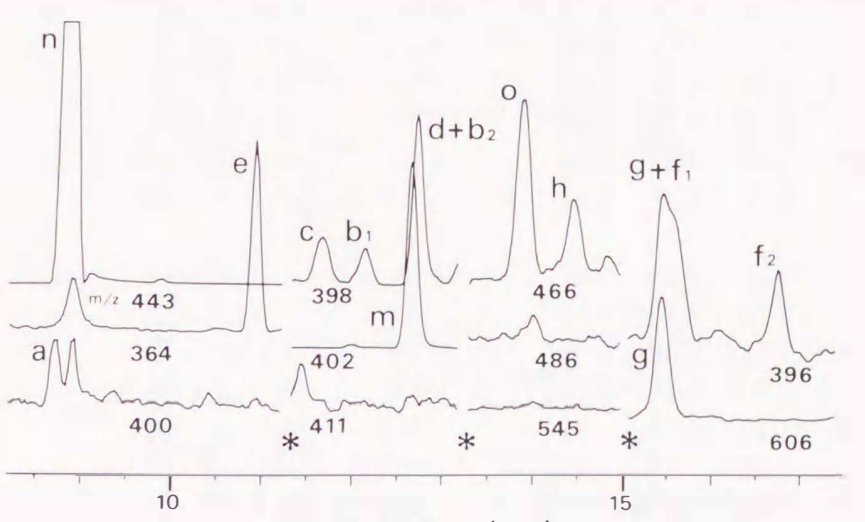

Fig. 3. Selection ion chromatogram of the Et-MO-DMES ether derivatives of keto bile acid ethyl esters in extract from sera of normal man ( $a-h, m, n$, Table III). The peak o was derived from $\left[{ }^{2} \mathrm{H}_{4}\right] \mathrm{CDCA}$ 
$\mathrm{MOA} \cdot \mathrm{HCl}$ in pyridine [29]. Table IV gives the relative areas of the isomers on the selected ion chromatogram of the Et-MO-DMES ether derivatives. Representative selected ion recordings of a mixture of authentic keto bile acids and bile acids in healthy human serum are shown in Figs. 2 and 3. The keto bile acid peaks were clearly separated without interference from dominant hydroxy bile acids and endogenous substances present in serum.

Deuterium-labelled bile acids used as internal standards

In order to determine accurately keto bile acids in biological specimens, it is essential to use a multi-deuterium-labelled keto bile acid as an internal standard. Therefore, $\left[{ }^{2} \mathrm{H}_{4}\right] 7 \mathrm{KLCA}$ was prepared from $\left[{ }^{2} \mathrm{H}_{4}\right] \mathrm{CDCA}$ with $7 \alpha$-HSD in our laboratory. Mass spectra of the Et-MO-DMES ether derivatives of unlabelled and labelled 7KLCA thus obtained are shown in Fig. 4. As the labelled compound has no fragment ions originating from a native bile acid, it can be used as an internal standard for their quantification by GC-SIM. $\left[{ }^{2} \mathrm{H}_{4}\right]$ CDCA was used as a representative internal standard for non-keto bile acids.

The calibration graphs for twelve keto and six hydroxy bile acids were prepared and regression equations were calculated using the method of least squares. There were good linearities in the range $2-100 \mathrm{pmol}$ for keto bile acids, lithocholic acid (LCA), ursodeoxycholic acid (UDCA) and $3 \beta$-hydroxy-5-cholenoic acid and 20-1000 pmol for cholic acid (CA), chenodeoxycholic acid $($ CDCA ) and deoxycholic acid (DCA) (correlation coefficient >0.9993).

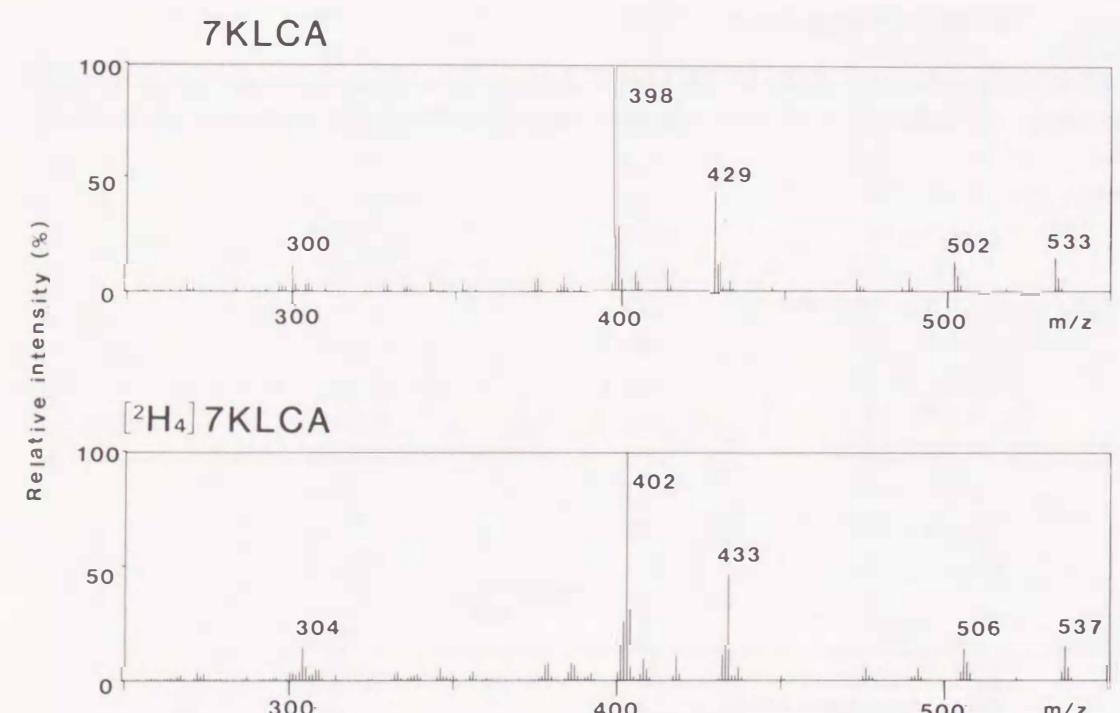

Fig. 4. Mass spectra of the Et-MO-I) MFS ether derivative of $3 \alpha$-hydroxy-7-ox(0-5/-cholanoic acid (7KL,CA, above) and $\left[{ }^{2} \mathrm{H}_{4}\right] 3 \alpha$-hydroxy-7-oxo-5/3-cholanoic acid $\left(\left[{ }^{2} \mathrm{H}_{4} \mid 7 \mathrm{KLCA}\right.\right.$, below ).
TABLE V

RECONERIES OF KETOO BILE ACIIS

The recoveries were calculated by dividing the amount recovered by that of the bile acid added The estimated amounts and their confidence limits were obtained according to the orthogona molynomial equat ion.

\begin{tabular}{|c|c|c|c|c|c|c|c|}
\hline \multirow{2}{*}{$\begin{array}{l}\text { Bile acid } \\
3 \mathrm{~K}\end{array}$} & $\begin{array}{l}\text { Sample } \\
\left(\mathbf{X}_{\mathrm{x}}+n \times\right)^{a} \\
(n=0.1 .2 .3)\end{array}$ & \multirow{2}{*}{$\begin{array}{l}\text { Amount } \\
\text { added } \\
(\mathrm{pmol} / \mathrm{ml}) \\
0\end{array}$} & \multicolumn{2}{|c|}{$\begin{array}{l}\text { Amount } \\
\text { found } \\
(p m o l / m l)\end{array}$} & \multicolumn{2}{|r|}{$\begin{array}{l}\text { Recovery } \\
\text { (mean } \pm S .(1) \text {.) } \\
\text { (ci) }\end{array}$} & \multirow{2}{*}{$\begin{array}{l}\text { Estimated amount } \\
\pm 95 \text { to confidence } \\
\text { limit } \\
4.5 \pm 2.9\end{array}$} \\
\hline & $A\left(X_{a}\right)$ & & 2.6 & 3.7 & 3.1) & & \\
\hline & $B \quad\left(\mathbf{X}_{a}\right)$ & () & 2.8 & 4.4 & 5. 3 & & \\
\hline & $(c)\left(X_{u}+a\right)$ & 19.8 & $17.0)$ & 21.8 & 18.5 & $68.4 \pm 1.4 .1)$ & \\
\hline & 1) $\left(\mathrm{X}_{\mathrm{a}}+\mathrm{a}\right)$ & 19.8 & 17.9 & 14.6 & 13.3 & & \\
\hline & $\mathrm{E} \quad\left(\mathrm{X}_{\mathrm{a}}+2 \mathrm{a}\right)$ & 39.6 & 35.7 & 32.7 & $33 . .3$ & $8(1.2 \pm 4.0$ & \\
\hline & $\mathrm{F} \quad\left(\mathrm{X}_{\mathrm{a}}+2 \mathrm{a}\right)$ & 39.6 & 37.8 & 34.4 & 36.6 & & \\
\hline & $\left(i\left(X_{a}+3 a\right)\right.$ & 59.4 & 52.4 & 47.9 & 50.1 & $7 . .5 \pm 6.0$ & \\
\hline & $H\left(X_{a}+3 a\right)$ & 59.4 & 50.5 & 42.4 & 4.4 .2 & & \\
\hline \multirow[t]{8}{*}{$3 \mathrm{~K} 7 \alpha$} & A $\left(X_{n}\right)$ & () & 14.4 & 13.7 & 16.6 & & $14.9 \pm 3.3$ \\
\hline & B $\quad\left(X_{1}\right)$ & () & 15.9 & 12.7 & 13.1 & & \\
\hline & $\left(X_{1},+b\right)$ & 24.0 & 39.2 & 37.9 & 37.8 & $88.6 \pm 11.8$ & \\
\hline & I) $\left(X_{1},+b\right)$ & 24.0 & 35.1 & 31.3 & 32.9 & & \\
\hline & E $\quad\left(X_{1},+2 b\right)$ & 48.0 & 67.4 & 58.0 & 64.1 & $98.6 \pm 8.2$ & \\
\hline & $\mathrm{F} \quad\left(\mathrm{X}_{\mathrm{b}},+2 \mathrm{~h}\right)$ & 48.0 & 62.6 & 5.5 .5 & 63.0 & & \\
\hline & $\left(; \quad\left(x_{1},+3 b\right)\right.$ & 72.0 & 81.8 & 88.9 & 82.8 & $9: 3.7 \pm 4.8$ & \\
\hline & $\mathrm{H} \quad\left(\mathrm{X}_{\mathrm{b}},+3 \mathrm{~h}\right)$ & $72.0)$ & 80.6 & 78.2 & 79.2 & & \\
\hline \multirow[t]{8}{*}{$3 K 12 \alpha$} & $A\left(X_{c}\right)$ & () & 15.6 & 13.9 & 13.9 & & $14.9 \pm 3.4$ \\
\hline & $\mathrm{B} \quad\left(\mathrm{X}_{\mathrm{c}}\right)$ & () & 15.5 & 13.1 & 14.4 & & \\
\hline & $(c)\left(X_{c}+c\right)$ & 2.2 .6 & 37.4 & 32.4 & 34.3 & $89.6 \pm 7.9$ & \\
\hline & I) $\left(X_{c}+c\right)$ & 22.6 & 36.6 & 333.2 & 36.2 & & \\
\hline & E $\quad\left(\mathrm{X}_{c}+2 c\right)$ & 45.2 & 56.3 & 61.3 & 62.6 & $98.7 \pm 5.1$ & \\
\hline & $\mathrm{F} \quad\left(\mathrm{X}_{\mathrm{c}}+2 \mathrm{C}\right)$ & 45.2 & $6(1) .2$ & 57.0 & 61.4 & & \\
\hline & $\left(\mathrm{B} \quad\left(\mathrm{X}_{\mathrm{c}}+3 \mathrm{c}\right)\right.$ & 67.8 & 81.6 & 86.6 & 81.5 & $93.9 \pm 8.1$ & \\
\hline & $\mathrm{H} \quad\left(\mathrm{X}_{\mathrm{c}}+3 \mathrm{C}\right)$ & 67.8 & 68.1 & 81.1 & 75.6 & & \\
\hline \multirow[t]{8}{*}{ ¿KLCA } & A $\quad\left(X_{d}\right)$ & () & 62.4 & 65.8 & 66.0 & & $68.5 \pm 9.6$ \\
\hline & $B \quad\left(X_{d}\right)$ & () & 61.8 & 62.2 & 64.7 & & \\
\hline & C $\left(X_{d}+d\right)$ & 62 & 120.0 & 125.7 & 1333.4 & $103.1 \pm 8.1$ & \\
\hline & I) $\left(\mathbf{X}_{\mathrm{d}}+\mathrm{d}\right)$ & 62 & 124.1 & 129.6 & 1333.8 & & \\
\hline & E $\quad\left(X_{d}+2 d\right)$ & 124 & 172.2 & 166.8 & 164.7 & $84.6 \pm 3.2$ & \\
\hline & $\mathrm{F} \quad\left(\mathrm{X}_{\mathrm{d}}+2 \mathrm{~d}\right)$ & 124 & 174.4 & 163.7 & $17(0.4$ & & \\
\hline & $\left(\mathrm{i} \quad\left(\mathrm{X}_{\mathrm{d}}+3 \mathrm{~d}\right)\right.$ & 186 & 236.9 & 248.4 & 244.5 & $96.4 \pm 2.7$ & \\
\hline & $\mathrm{H} \quad\left(\mathrm{X}_{\mathrm{d}}+3 \mathrm{~d}\right)$ & 186 & $240 .()$ & 250.4 & $2: 39.0$ & & \\
\hline
\end{tabular}


TARLEV (continued)

\begin{tabular}{|c|c|c|c|c|c|c|c|c|}
\hline \multirow{2}{*}{\multicolumn{2}{|c|}{ 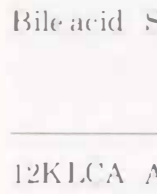 }} & Sample & \multirow{2}{*}{$\begin{array}{l}\text { Amount } \\
\text { added } \\
(\mathrm{pmol} / \mathrm{ml}) \\
0\end{array}$} & \multicolumn{2}{|c|}{$\begin{array}{l}\text { Amount } \\
\text { found } \\
\text { (pmol/ml) }\end{array}$} & \multicolumn{2}{|r|}{$\begin{array}{l}\text { Recovery } \\
\text { (mean } \pm \text { S.I).) } \\
\text { (s) }\end{array}$} & \multirow{2}{*}{$\begin{array}{l}\text { Est imated amount } \\
\pm 95^{\prime} " \mathrm{co} \text { confidence } \\
\text { limit } \\
10.7 \pm 2 .()\end{array}$} \\
\hline & & $\left(X_{e}\right)$ & & 10.7 & 8.3 & 9.5 & & \\
\hline & $B$ & $\left(X_{e}\right)$ & () & 10.1 & 9.6 & 11.5 & & \\
\hline & (c) & $\left(X_{e}+e\right)$ & 15.() & 23.5 & 23.3 & 25.5 & $97.2 \pm 8 .(1)$ & \\
\hline & I) & $\left(X_{e}+e\right)$ & 15.0 & $2: 3.4$ & 26.3 & 25.2 & & \\
\hline & $\mathrm{E}$ & $\left(X_{e}+2 e\right)$ & 30.0 & 36.7 & 36.7 & 35.5 & $84.2 \pm 4.7$ & \\
\hline & $\mathrm{F}$ & $\left(X_{e}+2 e\right)$ & 30.0 & 34.8 & 32.6 & 35.0 & & \\
\hline & (i & $\left(X_{e}+3 e\right)$ & 45.0 & 52.0 & 52.4 & 53.3 & $(94.5) \pm 3.8$ & \\
\hline & $\mathrm{Hi}$ & $\left(X_{e}+3 e\right)$ & $45 .()$ & 51.3 & $5 \pi .7$ & 50.3 & & \\
\hline \multirow[t]{8}{*}{$3 K T(x \mid 2 c x$} & $\mathrm{A}$ & $\left(X_{1}\right)$ & () & 9.6 & 12.0 & 9.3 & & $11.6 \pm 2.7$ \\
\hline & B & $\left(X_{1}\right)$ & () & $11 . \overline{)}$ & 12.6 & 11.3 & & \\
\hline & c & $\left(X_{1}+f\right)$ & 24.6 & 26.6 & 29.5 & 30.7 & $76.6 \pm 7.2$ & \\
\hline & I) & $\left(X_{1}+f\right)$ & 24.6 & 29.8 & 32.5 & 30.4 & & \\
\hline & $\mathrm{E}$ & $\left(X_{1}+2 f\right)$ & 49.2 & 57.6 & 52.6 & 57.7 & $87.4 \pm 5.3$ & \\
\hline & $\mathrm{F}$ & $\left(X_{i}+2 f\right)$ & 49.2 & 52.6 & 51.0 & 52.9 & & \\
\hline & (i) & $\left(X_{1}+3 f\right)$ & 73.8 & 78.3 & $7(0.5)$ & 73.9 & $86.4 \pm 4.9$ & \\
\hline & $\mathrm{H}$ & $\left(X_{1}+3 f\right)$ & 73.8 & 78.3 & 78.0 & $70.0)$ & & \\
\hline \multirow[t]{8}{*}{$7 \mathrm{KI})(\mathrm{A}$} & $A$ & $\left(X_{k}\right)$ & () & 13.6 & 12.7 & 15.9 & & $16.2 \pm 3.0$ \\
\hline & B & $\left(X_{k}\right)$ & () & 12.5 & 12.1 & 13.5 & & \\
\hline & (' & $\left(X_{k}+g\right)$ & $15 .()$ & 24.6 & 24.8 & 27.6 & $81.4 \pm 7.5$ & \\
\hline & I) & $\left(X_{k}+g\right)$ & 15.). & 26.6 & 25.0 & 25.0 & & \\
\hline & $\mathrm{E}$ & $\left(X_{k}+2 g\right)$ & 30.0 & 35.4 & 35.0 & 41.3 & $78.2 \pm 9.4$ & \\
\hline & $\mathrm{F}$ & $\left(X_{k}+2 g\right)$ & 30.0 & 34.6 & 34.4 & 40.3 & & \\
\hline & (i & $\left(X_{k}+3 g\right)$ & 45.0 & 52.1 & 48.2 & 47.9 & $82.2 \pm 5.9$ & \\
\hline & $\mathrm{H}$ & $\left(X_{k}+3 g\right)$ & $45 .()$ & $50(1) .3$ & 55.3 & 48.3 & & \\
\hline \multirow[t]{9}{*}{$12 K(1) C A$} & AA & $\left(X_{h}\right)$ & () & 12.4 & 11.1 & 10.0) & & $14.1 \pm 2.1$ \\
\hline & B & $\left(X_{h}\right)$ & () & 10.1 & 11.8 & 12.2 & & \\
\hline & (' & $\left(X_{h}+h\right)$ & 13.5 & 25.5 & $2: 3.2$ & $22.01)$ & $87 .(0 \pm 10.5)$ & \\
\hline & 1) & $\left(X_{h}+h\right)$ & 13.5 & 21.1 & 22.2 & $2: 3.4$ & & \\
\hline & E: & $\left(X_{h}+2 h\right)$ & $27 .(1)$ & 32.4 & 33.0 & 35.1 & $82.8 \pm 5 .(1)$ & \\
\hline & $\mathrm{F}$ & $\left(X_{h}+2 h\right)$ & $27 .(1)$ & 33.0 & 31.7 & 35.3 & & \\
\hline & (; & $\left(\mathrm{X}_{\mathrm{h}}+3 \mathrm{~h}\right)$ & $4(1.5)$ & 44.1 & 43.0 & 46.4 & $8.2 .3 \pm 5.3$ & \\
\hline & $\mathrm{H}$ & $\left(\mathrm{X}_{\mathrm{h}}+3 \mathrm{~h}\right)$ & 40.5 & 47.8 & $4: 3.3$ & 41.4 & & \\
\hline & & & & & & $R^{b}=$ & $87.1 \pm 1$ & \\
\hline
\end{tabular}

" $\mathrm{X}_{\mathrm{x}}=$ amount of keto bile acid present in serum; $n \mathrm{x}$ = amount of keto bile acid added to serum. "Mean of the recoveries of the individual bile acids added.
Statistical analysis of accuracy and precision

The accuracy and precision of the method when applied to the determination of keto bile acids in serum were investigated. Reproducibilities were checked by analysing five aliquots of the same serum sample in triplicate. The statis tical analysis was carried out according to a one-way layout in order to study the analytical errors due to sample preparation and measurement of SIM. The coefficient of variation of each keto bile acid, except 3-oxo-5 $\beta$-cholanoic acid, ranged from 2.3 to $11.5 \%$ for the sample preparation and from 3.1 to $11.0 \%$ for the selected ion recording.

Serum samples to which known amounts of eight keto bile acids have been added were analysed to determine the recoveries. Table $\mathrm{V}$ shows analytical data, the recoveries of keto bile acids, the estimated amounts of individual endogenous keto bile acids and the $95 \%$ confidence limits according to the orthogonal polynomial equation. The recoveries of individual keto bile acids added ranged from 74.4 to $94.7 \%$ with a mean of $87.1 \%$.

Keto bile acids in healthy human serum

The method was applied to the determination of keto and non-keto bile acids in serum from healthy subjects.

Eight keto bile acids, namely $3 \mathrm{~K}, 3 \mathrm{~K} 7 \alpha, 3 \mathrm{~K} 12 \alpha, 3 \mathrm{~K} 7 \alpha 12 \alpha, 7 \mathrm{KLCA}$,

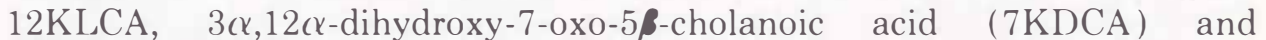
$12 \mathrm{KCDCA}$ were identified and quantified. Table VI summarizes the amounts of keto bile acids found in sera from ten healthy subjects. The mean and stan-

TABLEVI

KFTO BIL.F ACIDS IN SERUMM OF NORMAL, SUIB.JECTS

\begin{tabular}{|c|c|c|c|c|c|c|c|c|c|c|}
\hline \multirow[t]{2}{*}{ Subject } & \multicolumn{9}{|c|}{ Concentration (pmol/ml) } & \multirow{2}{*}{$\begin{array}{l}\text { Total } \\
\text { hydroxy bile } \\
\text { acids } \\
(\mathrm{nmol} / \mathrm{ml})\end{array}$} \\
\hline & $3 \mathrm{~K}$ & $3 \mathrm{~K} 7 \alpha$ & $3 \mathrm{~K} 12 \mathrm{Q} \mathrm{r}$ & $3 \mathrm{~K} 7 \alpha 12 \Theta$ & $7 \mathrm{KLCA}$ & $7 \mathrm{KI}) \mathrm{CA}$ & $12 \mathrm{KLCA}$ & $12 \mathrm{KCDCA}$ & Total & \\
\hline A & 3.7 & 14.4 & 14.4 & 10.4 & 63.8 & 13.4 & 10.0) & 11.3 & 141.4 & 6.72 \\
\hline $\mathrm{B}$ & 3.6 & 7.4 & 12.4 & 5.2 & 66. & 0 & 9.4 & 1. & 106.1 & 5.35 \\
\hline C & 7.0 & 7.9 & 38.0) & 0 & 23.4 & () & 102.4 & 2.6 & 181.3 & 13.57 \\
\hline I) & 10.7 & 12.9 & $10.0)$ & 11.0) & 42.5 & 11.6 & 14.4 & 7.4 & 120.5 & 7.15 \\
\hline $\mathrm{E}$ & 7.) & 9.2 & 33.4 & 6.7 & 31.9 & () & 53.4 & 3.4 & 145.0 & 4.31 \\
\hline F & 12.2 & 66.8 & 48.8 & 43.1 & 110.0 & 60.9 & 35.6 & 11.0) & 388.5 & 6.46 \\
\hline (i & 8.3 & 24.3 & 9.1 & 12.1 & 48.4 & 19.3 & 9.2 & 16.1 & 146.8 & 8.06 \\
\hline $\mathrm{H}$ & 8.0 & 22.5 & 24.9 & 6.6 & 47.1 & 27.4 & 37.3 & 10.2 & 184.0 & 5.72 \\
\hline I & 13.8 & 13.1 & 25.7 & () & () & () & 31.0) & () & 83.6 & 3.37 \\
\hline J & 12.0) & 6.7 & 14.6 & 4.7 & 38.5 & 26.1 & 23.5 & 6.9 & 133.0) & 2.88 \\
\hline Mea & 8.6 & 18. & 23.1 & 10) & 47 & 15 & 32. & 7.0) & 163.0 & 6.36 \\
\hline S.I). & 3.5 & 18.0) & 13.5 & 12.4 & 29.3 & 19.2 & 28.6 & 5.2 & 84.9 & 3.02 \\
\hline
\end{tabular}

${ }^{a}$ Sum of individual non-keto bile acids, i.e., lithocholic acid, 3/-hydroxy-5-cholenoic acid, deoxycholic acid, chenodeoxycholic acid, ursodeoxycholic acid and cholic acid. 
dard deviation of the total keto bile acids in serum was $163 \pm 81 \mathrm{pmol} / \mathrm{ml}$ and $2.9 \pm 1.5 \%$ of total usual hydroxy bile acids in peripheral serum.

Table VII shows the ratios of individual keto bile acids to their corresponding hydroxy bile acids calculated as 3K/LCA, $3 \mathrm{~K} 12 \alpha / \mathrm{DCA}, 3 \mathrm{~K} 7 \alpha / \mathrm{CDCA}$, $3 \mathrm{~K} 7 \alpha 12 \alpha / \mathrm{CA}, 7 \mathrm{KLCA} / \mathrm{CDCA}, 7 \mathrm{KDCA} / \mathrm{CA}, 12 \mathrm{KLCA} / \mathrm{DCA}$ and $12 \mathrm{KCDCA} /$ CA. Statistical analysis was carried out according to a paired $t$-test.

\section{DISCUSSION}

The presence of keto bile acids in human serum has been occasionally reported in patients suffering from hepatobiliary and intestinal diseases. However, their clinical significance is not clear. For instance, their composition in normal subjects was not known until recently because of the methodological difficulties.

One of the major problems in the determination of keto bile acids is their conversion to some other derivatives during alkaline hydrolysis [30]. To overcome this difficulty we used enzymatic hydrolysis with a long incubation time [31], which gave complete deconjugation of authentic tauro- and glycodehydrocholic acid added to serum without any formation of by-products. Recently Hirano et al. [32] proposed a rapid method for solvolysis using trifluoroacetic acid. A study on the possible incorporation of Hirano et al's solvolysis step [32] in the present analytical procedure for keto bile acids instead of Kornel's method [26] gave similar results and showed no statistical difference. As the former has the theoretical advantage of not inducing transesterification with the formation of acetate, which is a potential source of error if not followed by alkaline hydrolysis, the incorporation of Hirano et al.'s solvolysis step [32] seemed to be preferable.

Next, in order to protect carbonyl groups, especially the 3-oxo group, from enol ester formation during silylation [19], we used methyloxime derivatives because they have thermal stability, low polarity and good mass spectrometric properties and have been widely used in the GC-MS analysis of keto steroids $[19,27]$ and of prostaglandins [33]. However, steric hindrance prevented the complete conversion to methyloxime of the carbonyl groups on the steroid nucleus. For example, the 11-oxo group of steroids could not be converted completely under ordinary conditions owing to the interference from the two adjacent methyl groups at C-18 and C-19 [19]. Complete methyloxime derivatization of 3-, 7- and 12-keto groups of the bile acids was achieved by Sjövall's group [13,28,34-36]. In this work, the reaction rate of keto groups was determined and the methyloximation of the 7-oxo group of the bile acid ethyl ester was found to be slower than those of 12-and 3-oxo groups. However, complete conversion of carbonyl groups at C-3, C-7 and C- 12 of bile acids was successfully achieved within $60 \mathrm{~min}$ at $110^{\circ} \mathrm{C}$. Another advantage of utilizing methyloxime derivatization was the complete separation of some keto bile acids, 
which was difficult with the Me-TMS and Et-DMES ether derivatives on the non-polar HiCap-CBP1 capillary column. For example, the Et-DMES ether derivatives of 7KLCA and 12KLCA, which seem to be the major keto bile acids in sera, gave similar retention times and no specific fragment ion. In contrast, their corresponding $\mathrm{MO}$ derivatives could be separated completely and determined quantitatively. The 3-O-methyloxime DMES ether of bile acid ethyl esters gave two peaks corresponding to syn and anti isomers [27]. However, the quantification of 3-keto bile acids could be carried out without much difficulty, as the peak-area ratio of isomers was constant. In addition, the EtMO-DMES ether derivatives of some keto bile acids gave characteristic fragment ions with high intensity in the high-mass region, in contrast to the corresponding Et-DMES ether derivatives of bile acids with free carbonyl groups. Hence they are suitable for SIM. The accuracy and precision of the determination of keto bile acids in serum were established, except for 3-oxo-cholanoic acid, which constituted only a minor component. Therefore, by using the present method the simultaneous quantification of keto bile acids and the more dominant hydroxy bile acids in serum could be successfully achieved by SIM.

In this work, eight keto bile acids were newly identified and quantified in sera from healthy control subjects (Table VI). This is the first report on the profile of keto bile acids in normal sera. So far only two keto bile acids, viz., $12 \mathrm{KCDCA}$ and 7KDCA, have been reported to be present in sera of patients with hepatobiliary and intestinal disease $[16,17]$. In man numerous kinds of keto bile acids are present in faeces [3-6]. 7KLCA is known to be absorbed rom the intestine as efficiently as the hydroxy bile acids [37]. The presence of keto bile acids in portal blood has been reported [38]. Hence these newly identified keto bile acids in peripheral serum probably originate mainly in the intestine from the action of bacterial flora. However, the possibility of keto bile acids being diverted from the major metabolic pathway of cholesterol and hydroxy bile acids in the liver cannot be excluded.

Some $\beta$-hydroxy bile acids, especially UDCA, the $7 \beta$-epimer of CDCA, have been found in normal and disease states. However, their source still remains obscure. Carbonyl groups are reduced to $\alpha$ - or $\beta$-hydroxyl groups during passage through the liver [37,39-41]. The presence of keto bile acids in normal human serum suggests the possible formation of $\beta$-hydroxy bile acids from the corresponding keto bile acids in human liver under normal conditions.

The average total concentration of keto bile acids in this study was 0.16 $\mathrm{nmol} / \mathrm{ml}$ and constituted $2.9 \%$ of that of usual hydroxy bile acids. Although the total concentrations of keto bile acids in peripheral venous serum of cholelithiasis patients with a functioning gall bladder have been reported by Björkhem et al. [38] to be $0.18 \mathrm{nmol} / \mathrm{ml}$, corresponding to $9 \%$ of that of nonketo bile acids, the composition of individual keto bile acids was not known, as their method was based on the reduction of carbonyl groups of bile acids. The concentration range obtained in this study agrees well, but not the ratio of total keto to total non-keto bile acids. The lower figure for keto bile acids given by the present method is probably due to the omission of a solvolysis step on one hand and the determination of only three major hydroxy bile acids in their work on the other

Bile acids are thought to be subjected to redox reactions during enterohepatic circulation. A hydroxy bile acid may be oxidized to yield a corresponding keto bile acid and then reduced back to the original hydroxy bile acid. The keto/non-keto ratio in sera will reflect the balance between the hepatic reduction and bacterial oxidation. In this study, the 12KLCA/DCA ratio was significantly higher than the $12 \mathrm{KCDCA} / \mathrm{CA}$ ratio (Table VII). This result agreed well with the report by Björkhem et al. [42] that the hydroxy groups in DCA were more sensitive to redox reactions than the corresponding groups of $\mathrm{CA}$ It should be pointed that the level and composition of bile acids in peripheral serum reflect not only the biliary excretion and the bacterial degradation in the intestine but also the intestinal absorption and the hepatic extraction, which are in turn affected by the differences in their chemical structure, i.e. types of conjugation and numbers and positions of hydroxyl and carbonyl groups. Our knowledge of the hepatic extraction and intestinal absorption of keto bile acid is very limited. It seems possible, however, that the proportion of keto bile acids in serum reflects the capacity of the liver to reduce carbonyl groups of bile acids, as elevated levels of keto bile acids in urine in liver cirrhosis have been described [15].

In conclusion, a reliable method for the simultaneous determination of keto and non-keto bile acids in sera has been developed. Eight new keto bile acids were identified and quantified in sera of normal subjects. The profile of keto bile acids in sera may give an insight into bile acid metabolism in the enterohepatic circulation.

ACKNOWLEDGEMENTS

The authors are grateful to Dr. H. Ichimiya and Dr. J. Yanagisawa, Department of Surgery I, Kyushu University, Faculty of Medicine, for valuable discussions throughout this work.

\section{REFERENCES}

M.J. Hill and B.S. Drasar, Gut, 9 (1968) 22

V. Aries and M.J. Hill, Biochim. Biophys. Acta, 202 (1970) 535

P. Eneroth, K. Hellström and J. Sjïvall, Acta Chem. Scand., 22 (1968) 1729

K.I.R. Setchell, A.M. Lawson, N. Tanida and J. Sijövall, J. Lipid Res. 24 (1983) 1085

K.I.R. Setchell, J.A. Ives, G.C. Cashmore and A.M. Lawson, Clin. Chim. Acta, 162 (1987 257

6 R. Tandon, M. Axelson and J. Sjïvall, J. Chromatogr. 302 (1984) 1.

7 N. Matoba, M. Une and T. Hoshita, J. Lipid Res. 27 (1986) 1154. 
$8 \quad$ K. Kikuchi.J. Biochem. ('Tokyo), 72 (1972) 16.5

' (i.W. Hepner. A.F. Hofmann, J.R. Malagelada. P.A. Szczepanik and P.I). Klein, (Gastroenterology, 66 (1974) 5i66.

11) S. Matern.J. Sjïvall. E.W. Pomare, K.W. Heaton and T.S. L.ow-Beer, Med. Biol., 5;3 (1975)

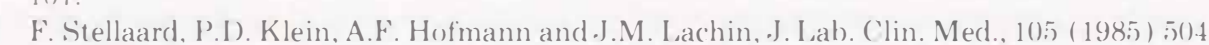
1.2 E. Andersén, (i. Karlaganis and J. Sjiovall, Eur. J. Clin. Invest., 18 (1988) 166.

1:3 B. Almé. A. Bremmelgaard. J. Sjiivall and P. Thomassen, J. Lipid Res., 8 (1977):339.

4 A. Bremmelyaard and J. Sjoivall, Eur. J. ('lin. Invest.., 9 (1979) 3441.

15) Y. Amuro, T. Endo, K. Higashino, K. Uchida and Y. Yamamura. ('lin. ('him. Acta. 114 (1981

16. A Hernany. R. Codoceo P. Jara and C Diaz (Clin Chim. Acta 145 (1985) 289

17 K.I.R. Setchell. I).L. Harrison. J.M. (iilhert and (i.M. Murphy. ('lin. (him. Acta. 152 (1985)

18 F. Nakayama .J Yanagisawa. H. Mivazaki and M. Itoh. J. (iastroenterol. Hepatol.. 2) (1987)

19) L... P. Thenot and F.C. Horning. Anal. Lett. is (1972) 21.

21) J Yamarisawa M Itoh M Ishibashi. H Miyazaki and F Nakayama, Anal Biochem. 104 (1980) 75 .

H. Miyazaki. M. Ishibashi and K. Yamashita. Biomed. Mass Spectrom... i (1978) 469

2.2. A. Fukunaga, Y. Hatta. M. Tshibashi and H. Miyazaki, J. ( Chromat ngr... 190 (1980) 3339.

K Fukudome K ( hijiwa T. Furusawa and F Nakayama Biochim Biophys Acta 9\% (1987) 155 .

T. Fujii, J. Yanagisawa and F. Nakayama, Digestion. 41 (1988) 207.

26 L. Kurnel. Biochemistry, 4 (1965) 444

27 M.C. Horning. A.M. Moss and F.C. Horning, Anal. Biochem., 22 (1968) 284

28 B. Almé and J. Sjövall. J. Steroid Biochem., 15 (1980) 907

29) ('H.L. Shackleton and J.W. Honour, (Tin. Chim. Acta, 69 (1976) 267.

30) (i. Lepage. A. Fontaine and ( C.C. Roy. J. Lipid Res.. 19 (1978) 5015

31 W.'T. Beher. S. Stradmeks. (i.R. Beher and (..J. L.In, Steroids. 32 ( 1978$) 355$.

32. Y. Hirano. H. Miyazaki and F. Nakayama, J. Lipid Res.. 28 (1987) 1524.

3.3 K. Ciréen. ('hem. Phys. Lipids. 3 (1969) 25.4.

3.4 T. ('ronholm, I. Makino and J. Sjiovall. Eur. J. Biochem., 24 (1972) 507

K. (arlstrom, D.N. Kirk and .. S.ovall, J. Lipid Res., 22 (1981) 122.

36 M. Axelson. B. Mork and J. Sjïvall. J. Lipid Res.. 29 (1988) 629.

37 H. Fromm. (i.L. Carlson, A.F. Hofmann, S. Farivar and P. Amin, Am. .J. Physionl., 2:39 (1980) (i161.

38 I. Björkhem, B. Angelin, K. Einarsson and S. Ewerth, J. Lipid Res.. 2:3 (1982) 1020.

39 R.I. Soloway, A.F. Hofmann. P.J. Thomas. L..J. Schoenfield and P.ID. Klein. J. Clin. Invest. $52(1973) 715$

40) M. Nakagaki. R.(i. I)anzinger, A.F. Hofmann and A. Reda. Am. J. Physiol.. 245) (198:3) (i41

41 I. Björkhem. K. Finarsson and (i. Hellers. Eur. J. Clin. Invest.. 33 (1973) 459

1.2 I. Björkhem L Liljequist, K. Nilsell and K. Finarsson, J Lipid Res '2T (1986) 177 . 


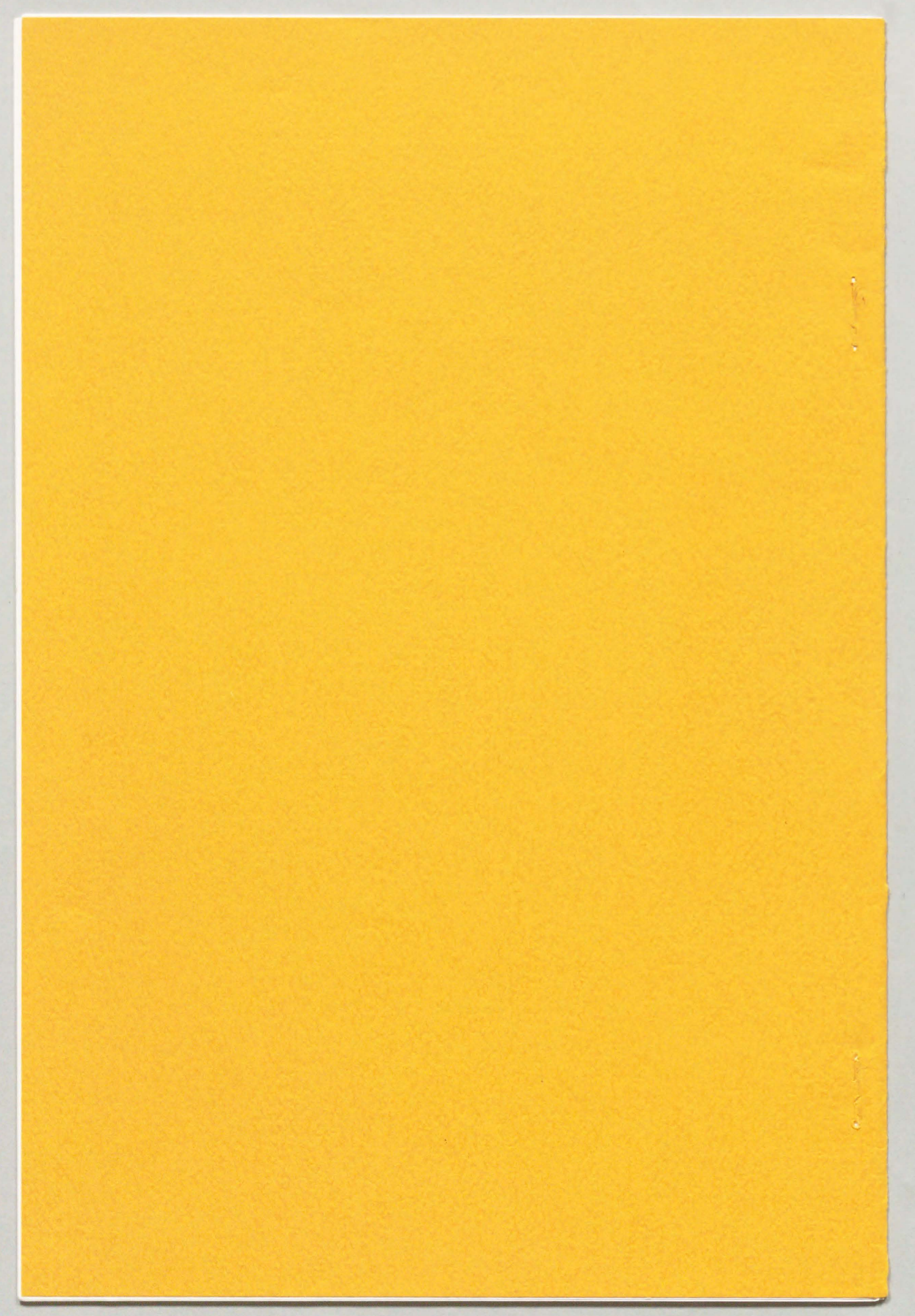

